Informatio: Journal of Library and Information Science Vol. 1(1), 31-48, Januari 2021

ISSN 2775-0043 (Online)

\title{
Hubungan pemanfaatan koleksi bahan pustaka dengan memenuhi kebutuhan informasi pengguna
}

\author{
Thalia Rizky Augustine ${ }^{\mathrm{a}^{*}}$, Prijana ${ }^{\mathrm{b}}$, Saleha Rodiahc \\ abc Fakultas Ilmu Komunikasi Universitas Padjadjaran Bandung
}

\begin{abstract}
Abstrak
Pemanfaatan koleksi bahan pustaka merupakan esensi penting dalam proses memenuhi kebutuhan informasi pengguna di taman bacaan masyarakat (TBM). Perkembangan ilmu pengetahuan dan teknologi memengaruhi kebutuhan masyarakat terhadap informasi. Kebutuhan ini disebabkan oleh rasa ingin tahu dan senantiasa ingin menambah pengetahuan. Dalam memenuhi kebutuhan informasi, taman bacaan masyarakat merupakan salah satu tempat yang menyediakan sumber informasi yang dapat dimanfaatkan oleh masyarakat. Penelitian ini bertujuan untuk mengetahui hubungan antara pemanfaatan koleksi bahan pustaka dengan memenuhi kebutuhan informasi pengguna di TBM Batoe Api. Pemanfaatan koleksi bahan pustaka diukur menggunakan dimensi frekuensi, durasi, alasan, tujuan, fasilitas, kenyamanan fasilitas, dan kelengkapan fasilitas. Memenuhi kebutuhan informasi diukur menggunakan dimensi kebutuhan informasi mutakhir, kebutuhan informasi rutin, kebutuhan informasi mendalam, dan kebutuhan informasi sekilas. Penelitian ini menggunakan metode pendekatan kuantitatif dengan metode korelasi. Teknik pengumpulan data dalam penelitian ini menggunakan kuesioner, observasi, dan studi kepustakaan. Teknik yang digunakan dalam penelitian merupakan salah satu teknik yang terdapat pada probability sampling method yakni simple random sampling. Populasi pada penelitian ini adalah anggota TBM Batoe Api, dengan sampel berjumlah 150 orang anggota TBM Batoe Api. Teknik analisis yang digunakan adalah teknik analisis data deskriptif dan analisis inferensial. Hasil dari penelitian ini menunjukkan adanya hubungan yang signifikan antara pemanfaatan koleksi bahan pustaka dengan memenuhi kebutuhan informasi yang memiliki dimensi kebutuhan informasi mutakhir, kebutuhan informasi rutin, kebutuhan informasi mendalam, dan kebutuhan informasi sekilas, yang telah terpenuhi dengan baik. Dalam hal penataan buku, pengelola TBM Batoe Api melakukannya dengan baik. Kedepannya, diharapkan penyusunan buku di TBM Batoe Api dapat mengikuti standar baku yang sudah ditetapkan dalam standar nasional perpustakaan walau Batoe Api merupakan taman bacaan masyarakat.
\end{abstract}

Kata kunci: Pemanfaatan koleksi bahan pustaka; Kebutuhan informasi; Taman bacaan masyarakat

Korespondensi: Thalia Rizky Augustine, Fakultas Ilmu Komunikasi, Universitas Padjadjaran, Jl. Ir. Soekarno Km. 21, Jatinangor, Sumedang, Jawa Barat 45363, Indonesia

Email: thaliaaugustine444@gmail.com

http://jurnal.unpad.ac.id/informatio

DOI: https://doi.org/10.24198/inf.v1i1.31064

Received: Desember 2020; Accepted: Januari 2021; Published: Januari 2021

(C) Informatio 2021. This is an open access article under the CC BY-SA license 


\title{
The relation between the use of library material collections to meet the user's information needs
}

\begin{abstract}
The use of library material collections is essential in meeting the user's information needs in Community Reading Park (TBM). The development of science and technology affects people's need for information because of their curiosity and desire to improve knowledge. In fulfilling information needs, Community Reading Park is one of places providing information sources that can be used by the community. This study aims to determine the relationship between the utilization of library material collections and fulfilling the users' information needs in Community Reading Park of Batoe Api. The use of library material collections was measured with some criteria: frequency, duration, reasons, objectives, facilities, coziness, and completeness. Fulfilling information needs was measured with the dimensions of current need approach, everyday need approach, exhaustic need approach, and catching-up need approach. This study was quantitative with correlation method. Data collection techniques in this article were questionnaire, observation, and library research. The sampling method used in this study was taken from one of the probability sampling methods, namely simple random sampling. The population in this study were 150 members of Community Reading Park of Batoe Api. The analysis technique used was descriptive method of data analysis and inferential analysis. The results of this study indicate a significant relationship between the utilization of library material collections and fulfilling information needs with dimensions of the four approaches mentioned above. In terms of book arrangement, TBM Batoe Api did well, and in the future, it is hoped that the arrangement can follow that of the library national standards despite its status as a Community Reading Park.
\end{abstract}

Keywords: The utilization of library material collection; Information needs; Community Reading Park

\section{PENDAHULUAN}

Perkembangan ilmu pengetahuan dan teknologi (IPTEK) semakin berkembang pesat. Hal ini dapat menimbulkan berbagai dampak, salah satunya adalah semakin besarnya kebutuhan masyarakat akan informasi. Kebutuhan informasi disebabkan oleh rasa ingin tahu dan senantiasa ingin menambah pengetahuan (Krisvaresi, 2013). Taman bacaan masyarakat (TBM) merupakan salah satu sumber informasi yang dapat digunakan masyarakat untuk memenuhi kebutuhan informasi.

Badan Pusat Statistik (BPS) yang mengadakan survei pada 2012 menyatakan masyarakat di Indonesia belum menjadikan aktivitas membaca sebagai sumber utama untuk memperoleh informasi. Masyarakat lebih menyukai aktivitas menonton TV (85\%) dan atau mendengarkan radio (40,3\%) daripada membaca koran (23,5\%) (Wardani, 2013). Hasil peliputan Pikiran Rakyat mengenai minat baca masyarakat Kabupaten Sumedang relatif rendah. Kepala Dinas Arsip dan Perpustakaan Daerah Kabupaten Sumedang menargetkan kunjungan masyarakat terutama para pelajar dan mahasiswa berjumlah 37.000 orang pada 2016, hanya mencapai dibawah 50\%. Situasi tersebut dikarenakan minat baca masyarakat yang kurang, sarana dan fasilitas yang kurang memadai (Jukardi, 2017). Taman Bacaan Masyarakat adalah tempat yang sengaja dibuat pemerintah, perorangan atau swakelola dan

Hubungan pemanfaatan koleksi bahan pustaka dengan memenuhi kebutuhan informasi pengguna

(Thalia Rizky Augustine, Prijana, Saleha Rodiah) 
swadaya masyarakat untuk menyediakan bahan bacaan dan menumbuhkan minat baca kepada masyarakat yang sengaja dibuat dan dikelola oleh masyarakat, perorangan, lembaga dan pemerintah untuk menumbuhkan minat baca kepada masyarakat yang ada di lingkungan taman bacaan tersebut (Sutarno, 2008).

TBM berfungsi untuk memberikan kesempatan kepada masyarakat dalam mencari informasi yang dibutuhkan dengan cara memanfaatkan koleksi TBM secara maksimal agar dapat memenuhi kebutuhan informasi. TBM bermanfaat bagi masyarakat karena dapat memberi kesempatan kepada mereka untuk memperoleh peningkatan pengetahuan dan keterampilan serta harapan dalam meningkatkan taraf kehidupan. Terdapat lima fungsi TBM yang salah satunya menyebutkan bahwa TBM berfungsi sebagai sumber informasi yang bersumber dari buku dan koleksi lainnya yang sesuai dengan kebutuhan warga belajar dan masyarakat setempat (Direktorat Pendidikan Masyarakat, 2003).

Batoe Api merupakan taman bacaan masyarakat yang ada di daerah kecamatan Jatinangor, kota Sumedang. Di Jatinangor terdapat empat institusi perguruan tinggi, maka tidak diragukan lagi bahwa Batoe Api memiliki koleksi yang memadai termasuk dengan penyelenggaraan pengadaan koleksi bahan pustaka. TBM Batoe Api sendiri merupakan perwujudan dari keinginan pengelola untuk memiliki sebuah taman bacaan dimana isinya adalah koleksi pribadi yang dapat dibaca juga oleh khalayak. Koleksinya terdiri dari buku, film, musik, kliping dan jurnal ilmiah, yang berasal dari internal milik pengelola dan hibah dari anggotanya. Batoe Api buka mulai pukul 10.00 WIB s.d. 18.00 WIB dari hari Senin sampai Sabtu dan melayani hingga 2.000 pengguna. Batoe Api dikelola oleh dua orang staf.

Aktivitas pemanfaatan koleksi terlihat dari banyaknya pengguna yang datang ke Batoe Api untuk menggunakan koleksinya, terutama buku-buku sastra dari berbagai daerah. Berdasarkan hasil wawancara dan observasi dari narasumber, pengguna disana juga tak jarang melakukan kegiatan diskusi di Batoe Api. Pengguna umumnya lebih suka meminjam koleksi bahan pustaka untuk dibawa pulang daripada membacanya di tempat. Batoe Api berusaha meningkatkan koleksi, fasilitas serta sarana dan prasarana, seperti mulai menambah koleksi bahan pustaka yang terbaru dan melengkapi fasilitas agar memudahkan pengguna. Selain itu, Batoe Api memiliki media sosial Instagram agar pengguna dapat mengetahui perkembangan koleksi bahan pustaka, fasilitas dan kegiatan yang diselenggarakan.

Pemanfaatan berasal dari kata manfaat yang merupakan sebuah cara, proses, dan perbuatan memanfaatkan sesuatu untuk suatu keperluan. Seluruh aspek dalam kehidupan manusia tidak dapat dipisahkan dari keberadaan informasi. Informasi yang baik dan berguna diharapkan mampu menunjang peningkatan pola kehidupan, sehingga kehidupan 
manusia dapat terus menerus mencapai kompleksitas yang semakin meninggi (Yusup \& Subekti, 2010). Jika dikaitkan dengan kebutuhan informasi, pemanfaatan koleksi bahan pustaka di TBM merupakan sebuah kegiatan yang dilakukan dalam memanfaatkan berbagai sumber informasi yang terdapat dalam koleksi untuk memenuhi kebutuhan informasi.

Menurut Wilson, model pencarian informasi (information seeking model) yaitu penemuan informasi berawal dari seorang pengguna membutuhkan informasi, dari kebutuhan ini maka timbul perilaku penemuan informasi. Agar memperoleh informasi yang dibutuhkan, pengguna dapat menggunakan sistem informasi atau melalui sumbersumber informasi lain untuk memperoleh informasi. Perilaku pencarian informasi ini memiliki dua kemungkinan, yaitu berhasil atau gagal. Kategori termasuk berhasil apabila pengguna menemukan informasi yang sesuai dengan kebutuhannya, dan termasuk gagal apabila pengguna tidak menemukan informasi yang dibutuhkannya sama sekali. (Hadid, 2017).

Hal tersebut seperti yang terjadi pada koleksi bahan pustaka Batoe Api yang kerap dimanfaatkan pengguna untuk memperoleh informasi yang dibutuhkan mereka, yakni:

"Koleksi Batoe Api yang beragam memiliki informasi yang dibutuhkan anggota perpustakaan. Setelah anggota menerima koleksi yang dicarinya, mereka menerima pengetahuan baru dari koleksi tersebut. Untuk menerima pengetahuan baru ini, mereka harus menggunakan koleksi melalui membaca, melihat dan mendengarkan" (Rukmana, Agustini, \& Yusup, 2015).

Namun demikian terdapat beberapa kendala dalam menjalankan TBM Batoe Api. Dengan adanya keluhan langsung yang didapat peneliti di Batoe Api dari beberapa mahasiswa terkait kurangnya koleksi referensi umum seperti yang dinyatakan oleh Muhammad Gemilang, mahasiswa Sastra Indonesia Universitas Padjadjaran dan Damarwan Syahid, mahasiswa Jurnalistik, yang mengeluhkan koleksi Batoe Api untuk sumber referensi masih belum lengkap untuk memenuhi kebutuhan dalam menyelesaikan tugas mereka. Karena satu judul buku hanya berjumlah satu sampai dua koleksi sedangkan pengguna Batoe Api sangat banyak. Berdasarkan hal tersebut, muncul pertanyaan dalam benak peneliti, apakah koleksi bahan pustaka yang ada di Batoe Api telah dapat memenuhi kebutuhan informasi para pengguna dengan kondisi koleksi yang ada karena pengguna kerap memanfaatkannya untuk penyelesaian masalahnya.

Oleh karena itu, berdasarkan latar belakang, penelitian ini memiliki rumusan masalah yakni pemanfaatan koleksi oleh pengguna Batoe Api sehingga di masa mendatang akan diketahui sampai mana para pengguna memanfaatkan koleksi bahan pustaka serta tinggi rendahnya kepuasan pemanfaatan koleksi bahan pustaka tersebut dipengaruhi oleh hal apa, 
khususnya dalam ranah memenuhi kebutuhan informasi pengguna. Peneliti menetapkan judul penelitian ini adalah "Hubungan pemanfaatan koleksi bahan pustaka dengan memenuhi kebutuhan informasi pengguna”.

Atas rumusan masalah tersebut didapati hipotesis, diantaranya: 1) $H_{0}$ : Tidak memiliki hubungan signifikan antara pemanfaatan koleksi bahan pustaka dengan memenuhi kebutuhan informasi pengguna; 2) $H_{1}$ : Memiliki hubungan signifikan antara pemanfaatan koleksi bahan pustaka dengan memenuhi kebutuhan informasi pengguna. Hipotesis dapat diartikan sebagai dugaan sementara sehingga diperlukan adanya pengujian menggunakan alat yang disebut dengan statistik. Sebuah hipotesis dalam penelitian uji statistik, hanya terdapat dua alternatif jawaban, yakni hipotesis diterima, atau hipotesis ditolak (Prijana, Winoto, \& Yanto, 2016).

Berdasarkan hal tersebut, penelitian ini memiliki tujuan diantaranya: 1) Untuk mengetahui hubungan pemanfaatan koleksi bahan pustaka dengan memenuhi kebutuhan informasi mutakhir pengguna; 2) Untuk mengetahui hubungan pemanfaatan koleksi bahan pustaka dengan memenuhi kebutuhan informasi rutin pengguna; 3) Untuk mengetahui hubungan pemanfaatan koleksi bahan pustaka dengan memenuhi kebutuhan informasi mendalam pengguna; 4) Untuk mengetahui hubungan pemanfaatan koleksi bahan pustaka dengan memenuhi kebutuhan informasi sekilas pengguna; 5) Untuk mengetahui hubungan pemanfaatan koleksi bahan pustaka dengan memenuhi kebutuhan informasi pengguna.

\section{METODE PENELITIAN}

Jenis penelitian ini yaitu penelitian kuantitatif dengan menggunakan metode korelasional. Metode ini digunakan untuk: 1) Mengukur ada tidaknya keterkaitan diantara berbagai variabel; 2) Memperkirakan variabel tidak bebas independen atas pengetahuan kita tentang variabel bebas; 3) Meratakan jalan untuk membuat rancangan penelitian eksperimental (Rakhmat, 2012). Penelitian ini melibatkan objek penelitian yaitu anggota TBM Batoe Api dengan sampel berjumlah 150 orang anggota TBM Batoe Api, Jalan Raya Jatinangor No. 142A, Jatinangor, Kabupaten Sumedang. Penelitian ini dimulai sejak Juli 2019 hingga selesai pada November 2019. Teknik yang digunakan dalam penelitian merupakan salah satu teknik yang terdapat pada probability sampling method yakni sampling acak sederhana. Menurut Sugiyono, sederhana merujuk kepada pengambilan sampel anggota populasi dilakukan secara acak dengan tidak memperhatikan tingkatan dalam populasi, sedangkan menurut Margono, untuk mendapatkan sampel yang langsung dilakukan pada unit sampling dapat menggunakan sample random sampling atau sampling acak sederhana (Dahlan, 2015). Pengguna koleksi bahan pustaka di TBM Batoe Api 
merupakan jenis populasi yang homogen. Ukuran sampel (size of sample) didapatkan melalui sampling error, selain itu sampling eror juga dapat digunakan untuk mencari parameter taksir, atau sebaliknya dengan menentukan taksir proporsi binomial (p\&q). Tabel ukuran sampling error yang digunakan dalam penelitian ini berjumlah 7,84 dengan proporsi binomial 60/40. 7,84 merupakan besaran sampling error yang digunakan oleh peneliti sebanyak 150 untuk ukuran sampel (Prijana et al., 2016).

Penelitian ini menggunakan teknik pengumpulan data diantaranya angket, observasi, wawancara, dan studi pustaka. Angket adalah instrumen utama, yang memuat sejumlah pertanyaan yang akan diisi oleh responden secara sadar. Angket disusun berdasarkan kerangka konsep dan indikator-indkator dari variabel penelitian yang telah dibahas. Selain itu, angket cocok digunakan kepada responden yang cukup besar jumlahnya. Angket pada penelitian ini berisi 25 pertanyaan. Terdiri atas 1) 8 jenis pertanyaan berbentuk open-ended question untuk data responden yang berjumlah 4 jenis pertanyaan dan close-ended question yang terdiri dari 4 pertanyaan; 2) 7 jenis pertanyaan mengenai pemanfaatan koleksi bahan pustaka (X); 3) 10 jenis pertanyaan mengenai pemenuhan kebutuhan informasi pengguna (Y). Observasi yaitu suatu proses yang kompleks, dimana proses ini terdiri dari berbagai proses biologis dan psikologis. Proses pengamatan dan ingatan merupakan dua bagian yang terpenting. Apabila penelitian berkenaan dengan perilaku manusia, proses kerja, gejala alam, dan bila responden yang diamati tidak terlalu besar, teknik pengumpulan data dengan observasi dapat digunakan. Teknik pengumpulan data studi kepustakaan dengan cara mengumpulkan dan menelaah informasi dari berbagai sumber literatur. Sumber informasi untuk penelitian dapat berupa buku laporan penelitian, internet, dan sebagainya yang relevan dengan permasalahan yang sedang diteliti (Sugiyono, 2012). Jika peneliti ingin melakukan studi pendahuluan untuk menemukan permasalahan yang perlu diteliti, dan juga apabila peneliti ingin mengetahui hal-hal lebih detail dan jumlah responden yang sedikit/kecil, teknik pengumpulan data yang tepat untuk digunakan yaitu wawancara.

Adapun teknik analisis data yang digunakan untuk penelitian ini yaitu analisis data deskriptif yang mencakup analisis data penelitian, analisis data responden, analisis kategori jawaban, dan analisis tabulasi silang (crosstab). Tujuan analisis data pada dasarnya menyederhanakan seluruh data yang terkumpul, menyajikan dalam suatu susunan yang sistematis, kemudian mengolah dan menafsirkan. Analisis deskriptif yaitu statistik yang digunakan untuk menganalisis data dengan cara mendeskripsikan atau menggambarkan data yang telah terkumpul memaparkan jawaban dari responden atas sejumlah pertanyaan yang diajukan dalam angket ke dalam bentuk tabel tunggal dan tabel silang untuk memberikan gambaran situasi yang terjadi (Sugiyono, 2009). 
Analisis statistik inferensial juga digunakan oleh peneliti dalam penelitian ini yang berfungsi untuk menemukan hubungan variabel bebas dengan variabel terikat. Analisis inferensial adalah analisis data sampel dan hasilnya diberlakukan untuk populasi. Statistik ini disebut sebagai statistic probabilitas, karena kesimpulan yang diberlakukan untuk populasi berdasarkan data sampel itu kebenarannya bersifat peluang. Analisis Pearson Product Moment digunakan peneliti untuk menganalisis hubungan sebab-akibat, diantara variabel independen $(\mathrm{X})$ dengan variabel dependen $(\mathrm{Y})$. Syarat skala pengukuran statistik yaitu sekurang-kurangnya interval, Korelasi Pearson Product Moment. Teknik Korelasi Pearson Product Moment merupakan teknik korelasi tunggal yang berfungsi untuk mencari koefisiensi korelasi antara data interval dan data interval lainnya (Bungin, 2005). Karena peneliti menggunakan analisis hubungan variabel sebab-akibat. Apabila data ordinal dimiliki, data tersebut harus dinaikkan terlebih dahulu dari ordinal ke interval. Pengujian korelasi dalam penelitian ini menggunakan software SPSS versi 22 (Prijana \& Yanto, 2020) dengan rumus:

$$
r=\frac{N \sum X i Y i\left(\sum X i\right)\left(\sum Y i\right)}{\sqrt{\left[N \sum X i^{2}-\left(\sum X i\right)^{2}\right]\left[N \sum Y i^{2}-\left(\sum Y i\right)^{2}\right]}}
$$

Keterangan:

$\begin{array}{ll}r & \text { : koefisien korelasi variabel } \mathrm{X} \text { dan } \mathrm{Y} \\ \mathrm{XY} & \text { : produk dari } \mathrm{X} \text { dan } \mathrm{Y} \\ \mathrm{X} & : \text { variabel } \mathrm{X} \\ \mathrm{Y} & \text { : variabel } \mathrm{Y} \\ \mathrm{N} & \text { : jumlah responden }\end{array}$

Uji hipotesis dilakukan menggunakan uji $t$ dengan ditetapkan tingkat signifikansi sebesar $\alpha=0,05$. Sedangkan kriteria penerimaan hipotesis penelitian adalah sebagai berikut: $t_{\text {hitung }} \geq t_{\text {tabal }}$ maka $H_{0}$ ditolak dan $H_{1}$ diterima, memiliki hubungan signifikan.

$t_{\text {hitung }} \leq t_{\text {tabal }}$ maka $H_{0}$ diterima dan $H_{1}$ ditolak, tidak memiliki hubungan signifikan.

Atau berbentuk hipotesis sebagai berikut:

$H_{0}$ : Tidak memiliki hubungan signifikan antara pemanfaatan koleksi bahan pustaka dengan memenuhi kebutuhan informasi pengguna.

$H_{1}$ : Memiliki hubungan signifikan antara pemanfaatan koleksi bahan pustaka dengan memenuhi kebutuhan informasi pengguna.

Uji hipotesis telah dilakukan, selanjutnya yakni interpretasi data menggunakan tabel tingkat hubungan koefisien menurut Guilford. Pertama, interval koefisien kurang dari 0,20 artinya memiliki tingkat hubungan lemah. Kedua, interval koefisien 0,20-0,40, memiliki tingkat hubungan rendah. Ketiga, interval koefisien 0,40-0,70, memiliki tingkat hubungan 
moderat. Keempat, interval koefisien 0,70 - 0,90, memiliki tingkat hubungan tinggi. Kelima, interval koefisien 0,90 - 1,00, memiliki tingkat hubungan sangat tinggi (Prijana et al., 2016).

\section{HASIL DAN PEMBAHASAN}

Angket yang terdiri dari 25 jenis pertanyaan disebarkan peneliti untuk melakukan penelitian ini. Terdiri dari 1) 8 jenis pertanyaan untuk data responden yang berbentuk open-ended question berjumlah 4 jenis pertanyaan dan close-ended question yang berjumlah 4 pertanyaan; 2) 7 jenis pertanyaan mengenai pemanfaatan koleksi bahan pustaka (X); 3) 10 jenis pertanyaan mengenai pemenuhan kebutuhan informasi pengguna (Y). Pertama, dalam pengujian pemanfaatan koleksi bahan pustaka (X) dengan memenuhi kebutuhan informasi mutakhir pengguna (Y1) menggunakan Pearson Product Moment melalui hipotesis sebagai berikut:

$\mathrm{H}_{0}$ : Tidak memiliki hubungan signifikan antara pemanfaatan koleksi bahan pustaka dengan memenuhi kebutuhan informasi mutakhir pemustaka.

$\mathrm{H}_{1}$ : Memiliki hubungan signifikan antara pemanfaatan koleksi bahan pustaka dengan memenuhi kebutuhan informasi mutakhir pemustaka.

Peneliti menggunakan aplikasi SPSS versi 22, dengan koefisien korelasi adalah 0,591 dan koefisien determinasi $r^{2}=0,05 \mathrm{dk}=150-2=148$.

Tabel 1. Korelasi Hubungan Pemanfaatan Koleksi Bahan Pustaka dengan Pemenuhan Kebutuhan Informasi Mutakhir

\begin{tabular}{cccc}
\hline & & X & Y1 \\
\hline $\begin{array}{c}\text { Pemanfaatan Koleksi } \\
\text { Bahan Pustaka }(X)\end{array}$ & Pearson Correlation & 1 & $.591^{* *}$
\end{tabular}

\begin{tabular}{|c|c|c|c|}
\hline & Sig. (2-tailed) & & .000 \\
\hline & $\mathrm{N}$ & 150 & 150 \\
\hline $\begin{array}{l}\text { Pemenuhan } \\
\text { Kebutuhan }\end{array}$ & Pearson Correlation & $.591^{*}$ & 1 \\
\hline
\end{tabular}

\begin{tabular}{ccc} 
Sig. (2-tailed) & .000 & \\
$\mathrm{~N}$ & 150 & 150 \\
\hline Sumber : Pengolahan data oleh Peneliti (2020)
\end{tabular}

Selanjutnya dilakukan uji signifikansi dengan tujuan mencari makna hubungan variabel independen $(\mathrm{X})$ dengan variabel dependen (Y1) dengan menggunakan rumus:

$$
t_{\text {hitung }}=\frac{r \sqrt{n-2}}{\sqrt{1-r^{2}}}
$$

Keterangan:

$t_{\text {hitung }} \quad$ nilai $\mathrm{t}$ 


$$
\begin{array}{ll}
r & : \text { nilai koefisien korelasi } \\
r^{2} & : \text { nilai koefisien determinasi } \\
\mathrm{n} & : \text { ukuran sampel }
\end{array}
$$

Peneliti mengetahui nilai di bawah ini:

$t_{\text {hitung }}=\frac{r \sqrt{n-2}}{\sqrt{1-r^{2}}}$

$t_{\text {hitung }}=\frac{0,591 \sqrt{150}-2}{\sqrt{1-0,345}}$

$t_{\text {hitung }}=\frac{7.189}{0,809}=8,88$

Nilai $t_{\text {tabel }}$ untuk dk $(\mathrm{n}-2)=148$ dengan $\alpha=0,05$ uji dua pihak atau $t$ wo tail test adalah 1,65

$t_{\text {hitung }} \geq t_{\text {tabel }}$ maka $H_{0}$ ditolak dan $H_{1}$ diterima

$t_{\text {hitung }} \leq t_{\text {tabel }}$ maka $H_{0}$ diterima dan $H_{1}$ ditolak

Hasil perhitungan $t_{\text {hitung }}(8,88) \geq t_{\text {tabel }}(1,65)$ maka $H_{0}$ ditolak dan $H_{1}$ diterima yang artinya pemanfaatan koleksi bahan pustaka berhubungan signifikan dengan pemenuhan kebutuhan informasi mutakhir. Berdasarkan hasil analisis diatas, hasil koefisien korelasi dari hubungan pemanfaatan koleksi bahan pustaka dengan pemenuhan kebutuhan informasi mutakhir adalah 0,591 dengan koefisien determinasi 0,345. Berdasarkan pada data yang diperoleh, didapat hasil $t_{\text {hitung }}$ sebesar 8,88 dengan $t_{\text {tabel }} 1,65$. Sehingga dapat diketahui bahwa tingkat derajat keeratan hubungan pemanfaatan koleksi bahan pustaka (X) dengan pemenuhan kebutuhan informasi mutakhir $\left(Y_{1}\right)$ adalah moderat.

Dari hasil penghitungan dan analisis yang dilakukan mengenai pemanfaatan koleksi bahan pustaka dengan pemenuhan kebutuhan informasi mutakhir, diperoleh hasil bahwa $H_{0}$ ditolak dan $H_{1}$ diterima. Artinya memiliki hubungan signifikan antara pemanfaatan koleksi bahan pustaka dengan pemenuhan kebutuhan informasi mutakhir dengan derajat keeratan moderat. Ketika pemanfaatan koleksi bahan pustaka perlu diperhatikan sebagai stimulus agar pemenuhan kebutuhan informasi mutakhir pengguna terpenuhi dengan baik.

Kedua, dalam pengujian pemanfaatan koleksi bahan pustaka (X) dengan memenuhi kebutuhan informasi rutin pengguna (Y2) menggunakan Pearson Product Moment melalui hipotesis sebagai berikut:

$\mathrm{H}_{0}$ : Tidak memiliki hubungan signifikan antara pemanfaatan koleksi bahan pustaka dengan memenuhi kebutuhan informasi rutin pemustaka.

$\mathrm{H}_{1}$ : Memiliki hubungan signifikan antara pemanfaatan koleksi bahan pustaka dengan memenuhi kebutuhan informasi rutin pemustaka.

Peneliti menggunakan aplikasi SPSS versi 22, dengan koefisien korelasi adalah 0,553 dan koefisien determinasi $r^{2}=0,05 \mathrm{dk}=150-2=148$. 
Tabel 2. Korelasi Hubungan Pemanfaatan Koleksi Bahan Pustaka dengan Pemenuhan Kebutuhan Informasi Rutin

\begin{tabular}{cccc}
\hline & & $\mathrm{X}$ & $\mathrm{Y} 2$ \\
\hline Pemanfaatan Koleksi & Pearson Correlation & 1 & $.553^{* *}$ \\
Bahan Pustaka (X) & & & \\
& Sig. (2-tailed) & & .000 \\
& $\mathrm{~N}$ & 150 & 150 \\
Pemenuhan & Pearson Correlation & $.553^{* *}$ & 1 \\
Kebutuhan & & & \\
Informasi (Y2) & Sig. (2-tailed) & .000 & \\
& $\mathrm{~N}$ & 150 & 150 \\
\hline
\end{tabular}

Sumber: Pengolahan data oleh Peneliti (2020)

Selanjutnya dilakukan uji signifikansi yang bertujuan mencari makna hubungan variabel independen $(\mathrm{X})$ dengan variabel dependen (Y2) dengan menggunakan rumus:

$$
t_{\text {nitung }}=\frac{r \sqrt{n-2}}{\sqrt{1-r^{2}}}
$$

\section{Keterangan:}

$t_{\text {nitung }} \quad$ nilai $\mathrm{t}$

$r \quad:$ nilai koefisien korelasi

$r^{2} \quad:$ nilai koefisien determinasi

$\mathrm{n} \quad$ : ukuran sampel

Peneliti mengetahui nilai di bawah ini:

$t_{\text {hitung }}=\frac{r \sqrt{n-2}}{\sqrt{1-r^{2}}}$

$t_{\text {hitung }}=\frac{0,553 \sqrt{150}-2}{\sqrt{1-0,301}}$

$t_{\text {nitung }}=\frac{6,727}{0,836}=8,04$

Nilai $t_{\text {tabel }}$ untuk dk $(\mathrm{n}-2)=148$ dengan $\alpha=0,05$ uji dua pihak atau two tail test adalah 1,65

$t_{\text {hitung }} \geq t_{\text {tabel }}$ maka $H_{0}$ ditolak dan $H_{1}$ diterima

$t_{\text {hitung }} \leq t_{\text {tabel }}$ maka $H_{0}$ diterima dan $H_{1}$ ditolak

Hasil perhitungan $t_{\text {hitung }}(8,04) \geq t_{\text {tabel }}(1,65)$ maka $H_{0}$ ditolak dan $H_{1}$ diterima. Artinya pemanfaatan koleksi bahan pustaka berhubungan signifikan dengan pemenuhan kebutuhan informasi rutin. Berdasarkan hasil analisis diatas, hasil koefisien korelasi dari hubungan pemanfaatan koleksi bahan pustaka dengan pemenuhan kebutuhan informasi mutakhir adalah 0,553 dengan koefisien determinasi 0,302. Sehingga didapat hasil $t_{\text {kitung }}$ sebesar 8,04 dengan $t_{t a b e l} 1,65$. Merujuk pada hasil di atas, diketahui bahwa tingkat derajat 
keeratan hubungan pemanfaatan koleksi bahan pustaka $(\mathrm{X})$ dengan pemenuhan kebutuhan informasi rutin $\left(Y_{2}\right)$ adalah moderat. Hasil penghitungan dan analisis yang dilakukan mengenai pemanfaatan koleksi bahan pustaka dengan pemenuhan kebutuhan informasi rutin, diperoleh hasil bahwa $H_{0}$ ditolak dan $H_{1}$ diterima. Artinya memiliki hubungan signifikan antara pemanfaatan koleksi bahan pustaka dengan pemenuhan kebutuhan informasi mutakhir dengan derajat keeratan moderat. Saat pemanfaatan koleksi bahan pustaka perlu diperhatikan sebagai stimulus agar pemenuhan kebutuhan informasi rutin pengguna terpenuhi dengan baik.

Ketiga, dalam pengujian pemanfaatan koleksi bahan pustaka (X) dengan memenuhi kebutuhan informasi mendalam pengguna (Y3) menggunakan Pearson Product Moment berdasarkan hipotesis berikut:

$\mathrm{H}_{0}$ : Tidak memiliki hubungan signifikan antara pemanfaatan koleksi bahan pustaka dengan memenuhi kebutuhan informasi mendalam pemustaka.

$\mathrm{H}_{1}$ : Memiliki hubungan signifikan antara pemanfaatan koleksi bahan pustaka dengan memenuhi kebutuhan informasi mendalam pemustaka.

Peneliti menggunakan aplikasi SPSS versi 22, dengan koefisien korelasi adalah 0,250 dan koefisien determinasi $r^{2}=0,05 \mathrm{dk}=150-2=148$.

Tabel 3. Korelasi Hubungan Pemanfaatan Koleksi Bahan Pustaka dengan Pemenuhan Kebutuhan Informasi Mendalam

\begin{tabular}{cccc}
\hline & & $\mathrm{X}$ & $\mathrm{Y3}$ \\
\hline Pemanfaatan Koleksi & Pearson Correlation & 1 & $.250^{* *}$ \\
Bahan Pustaka (X) & & & \\
& Sig. (2-tailed) & & .000 \\
& $\mathrm{~N}$ & 150 & 150 \\
Pemenuhan & Pearson Correlation & $.250^{* *}$ & 1 \\
Kebutuhan & & & \\
Informasi (Y3) & Sig. (2-tailed) & .000 & \\
& $\mathrm{~N}$ & 150 & 150 \\
\hline
\end{tabular}

Sumber: Pengolahan data oleh Peneliti (2020)

Selanjutnya dilakukan uji signifikansi dengan tujuan mencari makna hubungan variabel independen $(\mathrm{X})$ dengan variabel dependen $(\mathrm{Y} 3)$ dengan menggunakan rumus:

$$
t_{\text {hitung }}=\frac{r \sqrt{n-2}}{\sqrt{1-r^{2}}}
$$

Keterangan:

$\begin{array}{ll}t_{\text {hitung }} & \text { : nilai t } \\ r & : \text { nilai koefisien korelasi }\end{array}$




$$
\begin{array}{ll}
r^{2} & : \text { nilai koefisien determinasi } \\
\mathrm{n} & : \text { ukuran sampel }
\end{array}
$$

Peneliti mengetahui nilai di bawah ini:

$t_{\text {hitung }}=\frac{r \sqrt{n-2}}{\sqrt{1-r^{2}}}$

$t_{\text {hitung }}=\frac{0,250 \sqrt{150}-2}{\sqrt{1-0,056}}$

$t_{\text {hitung }}=\frac{3,041}{0,971}=3,13$

Nilai $t_{\text {tabal }}$ untuk dk $(n-2)=148$ dengan $\alpha=0,05$ uji dua pihak atau two tail test adalah 1,65

$t_{\text {hitung }} \geq t_{\text {tabal }}$ maka $H_{0}$ ditolak dan $H_{1}$ diterima

$t_{\text {hitung }} \leq t_{\text {tabal }}$ maka $H_{0}$ diterima dan $H_{1}$ ditolak

Hasil perhitungan $t_{\text {hitung }}(3,13) \geq t_{\text {tabel }}(1,65)$ maka $H_{0}$ ditolak dan $H_{1}$ diterima, artinya pemanfaatan koleksi bahan pustaka berhubungan signifikan dengan pemenuhan kebutuhan informasi mendalam. Berdasarkan hasil analisis di atas, hasil koefisien korelasi dari hubungan pemanfaatan koleksi bahan pustaka dengan pemenuhan kebutuhan informasi mendalam adalah 0,250 dengan koefisien determinasi 0,056. Sehingga didapat hasil $t_{\text {hitung }}$ sebesar 3,13 dengan $t_{\text {tabal }}$ 1,65. Merujuk pada hasil di atas, diketahui bahwa tingkat derajat keeratan hubungan pemanfaatan koleksi bahan pustaka (X) dengan pemenuhan kebutuhan informasi mendalam $\left(Y_{3}\right)$ adalah moderat.

Dari hasil penghitungan dan analisis mengenai pemanfaatan koleksi bahan pustaka dengan pemenuhan kebutuhan informasi mendalam, diperoleh hasil bahwa $H_{0}$ ditolak dan $H_{1}$ diterima. Artinya memiliki hubungan signifikan antara pemanfaatan koleksi bahan pustaka dengan pemenuhan kebutuhan informasi mendalam dengan derajat keeratan moderat. Dalam pemanfaatan koleksi bahan pustaka perlu diperhatikan sebagai stimulus agar pemenuhan kebutuhan informasi mendalam pengguna terpenuhi dengan baik.

Keempat, pengujian pemanfaatan koleksi bahan pustaka (X) dengan memenuhi kebutuhan informasi sekilas pengguna (Y4) menggunakan Pearson Product Moment melalui hipotesis sebagai berikut:

$\mathrm{H}_{0}$ : Tidak memiliki hubungan signifikan antara pemanfaatan koleksi bahan pustaka dengan memenuhi kebutuhan informasi sekilas pemustaka.

$\mathrm{H}_{1}$ : Memiliki hubungan signifikan antara pemanfaatan koleksi bahan pustaka dengan memenuhi kebutuhan informasi sekilas pemustaka.

Peneliti menggunakan aplikasi SPSS versi 22, dengan koefisien korelasi adalah 0,307 dan koefisien determinasi $r^{2}=0,05 \mathrm{dk}=150-2=148$. 
Tabel 4. Korelasi Hubungan Pemanfaatan Koleksi Bahan Pustaka dengan Pemenuhan Kebutuhan Informasi Sekilas

\begin{tabular}{cccc}
\hline & & $\mathrm{X}$ & $\mathrm{Y} 4$ \\
\hline Pemanfaatan Koleksi & Pearson Correlation & 1 & $.307^{* *}$ \\
Bahan Pustaka (X) & & & \\
& Sig. (2-tailed) & & .000 \\
& $\mathrm{~N}$ & 150 & 150 \\
Pemenuhan & Pearson Correlation & $.307^{* *}$ & 1 \\
Kebutuhan & & & \\
Informasi (Y4) & Sig. (2-tailed) & .000 & \\
& $\mathrm{~N}$ & 150 & 150 \\
\hline
\end{tabular}

Sumber: Pengolahan data oleh Peneliti (2020)

Selanjutnya dilakukan uji signifikansi yang bertujuan mencari makna hubungan variabel independen $(\mathrm{X})$ dengan variabel dependen (Y4) dengan menggunakan rumus:

$$
t_{\text {hitung }}=\frac{r \sqrt{n-2}}{\sqrt{1-r^{2}}}
$$

Keterangan:

$$
\begin{array}{ll}
t_{\text {hitung }} & \text { : nilai t } \\
r & : \text { nilai koefisien korelasi } \\
r^{2} & : \text { nilai koefisien determinasi } \\
\mathrm{n} & : \text { ukuran sampel }
\end{array}
$$

Peneliti mengetahui nilai di bawah ini:

$$
\begin{aligned}
& t_{\text {hitung }}=\frac{r \sqrt{n-2}}{\sqrt{1-r^{2}}} \\
& t_{\text {kitung }}=\frac{0,307 \sqrt{150}-2}{\sqrt{1-0,088}} \\
& t_{\text {hitung }}=\frac{3.7944}{0,954}=3,91
\end{aligned}
$$

Nilai $t_{\text {tabel }}$ untuk dk $(\mathrm{n}-2)=148$ dengan $\alpha=0,05$ uji dua pihak atau two tail test adalah 1,65

$t_{\text {hitung }} \geq t_{\text {tabal }}$ maka $H_{0}$ ditolak dan $H_{1}$ diterima

$t_{\text {hitung }} \leq t_{\text {tabel }}$ maka $H_{0}$ diterima dan $H_{1}$ ditolak

Hasil perhitungan $t_{\text {hitung }}(3,91) \geq t_{\text {tabal }}(1,65)$ maka $H_{0}$ ditolak dan $H_{1}$ diterima yang artinya pemanfaatan koleksi bahan pustaka berhubungan signifikan dengan pemenuhan kebutuhan informasi sekilas. Berdasarkan hasil analisis diatas, hasil koefisien korelasi dari hubungan pemanfaatan koleksi bahan pustaka dengan pemenuhan kebutuhan informasi sekilas adalah 0,307 dengan koefisien determinasi 0,088 sehingga didapat hasil $t_{\text {hitung }}$ 
sebesar 3,91 dengan $t_{\text {tabel }} 1,65$. Merujuk pada hasil di atas maka dapat diketahui bahwa tingkat derajat keeratan hubungan pemanfaatan koleksi bahan pustaka (X) dengan pemenuhan kebutuhan informasi sekilas $\left(Y_{4}\right)$ adalah moderat.

Hasil penghitungan dan analisis yang dilakukan mengenai pemanfaatan koleksi bahan pustaka dengan pemenuhan kebutuhan informasi sekilas, diperoleh hasil bahwa $H_{0}$ ditolak dan $H_{1}$ diterima. Artinya memiliki hubungan signifikan antara pemanfaatan koleksi bahan pustaka dengan pemenuhan kebutuhan informasi sekilas dengan derajat keeratan moderat. Ketika pemanfaatan koleksi bahan pustaka perlu diperhatikan sebagai stimulus agar pemenuhan kebutuhan informasi sekilas pengguna terpenuhi dengan baik.

Kelima, pengujian pemanfaatan koleksi bahan pustaka (X) dengan memenuhi kebutuhan informasi mutakhir pengguna (Y) menggunakan Pearson Product Moment melalui hipotesis sebagai berikut:

$\mathrm{H}_{0}$ : Tidak memiliki hubungan signifikan antara pemanfaatan koleksi bahan pustaka dengan memenuhi kebutuhan informasi pemustaka.

$\mathrm{H}_{1}$ : Memiliki hubungan signifikan antara pemanfaatan koleksi bahan pustaka dengan memenuhi kebutuhan informasi pemustaka.

Peneliti menggunakan aplikasi SPSS versi 22, dengan koefisien korelasi adalah 0,461 dan koefisien determinasi $r^{2}=0,05 \mathrm{dk}=150-2=148$.

Tabel 5. Korelasi Hubungan Pemanfaatan Koleksi Bahan Pustaka dengan Pemenuhan Kebutuhan Informasi

\begin{tabular}{cccc}
\hline & & $\mathrm{X}$ & $\mathrm{Y}$ \\
\hline Pemanfaatan Koleksi & Pearson Correlation & 1 & $.461^{*}$ \\
Bahan Pustaka (X) & & & \\
& Sig. (2-tailed) & & .000 \\
& $\mathrm{~N}$ & 150 & 150 \\
Pemenuhan & Pearson Correlation & $.461^{*}$ & 1 \\
Kebutuhan & & & \\
Informasi (Y) & Sig. (2-tailed) & .000 & \\
& $\mathrm{~N}$ & 150 & 150 \\
\hline
\end{tabular}

Sumber: Pengolahan data oleh Peneliti (2020)

Selanjutnya dilakukan uji signifikansi yang bertujuan mencari makna hubungan variabel independen $(\mathrm{X})$ dengan variabel dependen $(\mathrm{Y})$ dengan menggunakan rumus:

$$
t_{\text {hitung }}=\frac{r \sqrt{n-2}}{\sqrt{1-r^{2}}}
$$

Keterangan:

$t_{\text {hitung }} \quad$ nilai t 


$$
\begin{array}{ll}
r & : \text { nilai koefisien korelasi } \\
r^{2} & : \text { nilai koefisien determinasi } \\
\mathrm{n} & : \text { ukuran sampel }
\end{array}
$$

Peneliti mengetahui nilai di bawah ini:

$t_{\text {hitung }}=\frac{r \sqrt{n-2}}{\sqrt{1-r^{2}}}$

$t_{\text {hitung }}=\frac{0,461 \sqrt{150}-2}{\sqrt{1-0,207}}$

$t_{\text {hitung }}=\frac{5,608}{0,793}=7,07$

Nilai $t_{\text {tabel }}$ untuk dk $(\mathrm{n}-2)=148$ dengan $\alpha=0,05$ uji dua pihak atau two tail test adalah 1,65

$t_{\text {hitung }} \geq t_{\text {tabel }}$ maka $H_{0}$ ditolak dan $H_{1}$ diterima

$t_{\text {hitung }} \leq t_{\text {tabel }}$ maka $H_{0}$ diterima dan $H_{1}$ ditolak

Hasil perhitungan $t_{\text {hitung }}(7,07) \geq t_{\text {tabal }}(1,65)$ maka $H_{0}$ ditolak dan $H_{1}$ diterima yang artinya pemanfaatan koleksi bahan pustaka berhubungan signifikan dengan pemenuhan kebutuhan informasi. Berdasarkan hasil analisis di atas, hasil koefisien korelasi dari hubungan pemanfaatan koleksi bahan pustaka dengan pemenuhan kebutuhan informasi adalah 0,461 dengan koefisien determinasi 0,207. Sehingga didapat hasil $t_{\text {hitung }}$ sebesar 7,07 dengan $t_{t a b e l}$ 1,65. Merujuk pada hasil di atas, diketahui bahwa tingkat derajat keeratan hubungan pemanfaatan koleksi bahan pustaka $(\mathrm{X})$ dengan pemenuhan kebutuhan informasi mutakhir (Y) adalah moderat. Hasil penghitungan dan analisis yang dilakukan mengenai pemanfaatan koleksi bahan pustaka dengan pemenuhan kebutuhan informasi, diperoleh hasil bahwa $H_{0}$ ditolak dan $H_{1}$ diterima. Artinya memiliki hubungan signifikan antara pemanfaatan koleksi bahan pustaka dengan pemenuhan kebutuhan informasi dengan derajat keeratan moderat.

Pemanfaatan bahan pustaka untuk pemenuhan kebutuhan informasi relevan dengan Information Seeking Theory. Teori ini menyatakan terdapat faktor penting dalam penemuan informasi, yakni konteks kehidupan pencari informasi dengan menggunakan sistem informasi, dan sumber daya informasi yang dibutuhkan. Sumber daya yang dimaksud adalah informasi yang terkandung dalam koleksi taman bacaan masyarakat Batoe Api. Dengan demikian teori ini lebih memfokuskan pada pengguna sebagai objek dalam setiap tahap pencarian, penemuan, hingga penggunaan atau pemanfaatan informasi dalam rangka memenuhi kebutuhan informasi pengguna (Hadid, 2017). Saat pemanfaatan koleksi bahan pustaka perlu diperhatikan sebagai stimulus agar pemenuhan kebutuhan informasi pengguna dengan baik dapat terpenuhi. 


\section{SIMPULAN}

Kesimpulan yang diperoleh berdasarkan penelitian ini terbagi menjadi beberapa poin. Pertama, diketahui bahwa pemanfaatan koleksi bahan pustaka memiliki hubungan yang signifikan dengan pemenuhan kebutuhan informasi mutakhir pengguna taman bacaan masyarakat Batoe Api. Indikator dari dimensi memenuhi kebutuhan informasi pengguna adalah informasi terbaru dan informasi aktual yang disediakan taman bacaan masyarakat Batoe Api. Kedua, diketahui bahwa pemanfaatan koleksi bahan pustaka memiliki hubungan yang signifikan dengan pemenuhan kebutuhan informasi rutin pengguna TBM Batoe Api. Dimensi kebutuhan informasi rutin dipengaruhi informasi yang didapatkan secara rutin dan keragaman yang didapat pengguna. Penulis menemukan banyak pengguna yang berstatus mahasiswa mencari informasi spesifik, mengumpulkan data untuk penyelesaian tugas mereka. Ketiga, diketahui bahwa pemanfaatan koleksi bahan pustaka memiliki hubungan yang signifikan dengan pemenuhan kebutuhan informasi mendalam pengguna TBM Batoe Api. Banyaknya koleksi dengan berbagai subjek dan topik serta hampir semua literatur memiliki subjek yang relevan merupakan instrumen penting yang menjadi daya tarik dari TBM Batoe Api.

Kemudian keempat, diketahui bahwa pemanfaatan koleksi bahan pustaka memiliki hubungan yang signifikan dengan pemenuhan kebutuhan informasi sekilas pengguna TBM Batoe Api. Pengguna TBM Batoe Api terkadang perlu memiliki gambaran sekilas namun lengkap tentang perkembangan terkini dari topik yang tidak terlalu diminati atau tidak masuk dalam minat bidang utamanya sehingga dibutuhkan sistem komunikasi sebagai alat yang akan membantu pengguna mendapatkan subjek informasi dengan cepat. Kelima, diketahui bahwa pemanfaatan koleksi bahan pustaka memiliki hubungan yang signifikan dengan pemenuhan kebutuhan informasi pengguna TBM Batoe Api. Pada dasarnya pemanfaatan koleksi bahan pustaka merupakan salah satu inti dari pemenuhan kebutuhan informasi. Diharapkan TBM Batoe Api dapat mengoptimalkan lagi kualitas dan kuantitas koleksi yang dibutuhkan pengguna agar kebutuhan informasi dapat terpenuhi dengan baik.

Frekuensi pemanfaatan koleksi bahan pustaka TBM Batoe Api lebih rendah dibandingkan durasi pemanfaatan koleksi bahan pustaka TBM Batoe Api yang lebih tinggi. TBM Batoe Api diharapkan dapat melakukan event promotion perpustakaan yang dapat membuat pengguna sering datang. Contohnya adalah kegiatan screening film yang dulu rutin diadakan TBM Batoe Api tiap minggunya. Cukup banyak responden yang memanfaatkan koleksi bahan pustaka TBM Batoe Api bertujuan untuk mengerjakan tugas atau penelitian. Peneliti mengamati kurangnya fasilitas pendukung seperti stopkontak listrik dan tempat mengerjakan tugas yang memadai. Maka diharapkan TBM Batoe Api 
dapat menambah stopkontak listrik dan menyediakan tempat baru untuk pengguna mengerjakan tugas. Sebagai calon pustakawan, peneliti juga memberikan saran sesuai dengan standar nasional perpustakaan tentang penataan sesuai klasifikasi dan katalogisasi. Penataan buku di TBM Batoe Api sudah bagus dan rapi, namun akan lebih baik apabila penyusunan buku di TBM Batoe Api mengikuti standar baku yang sudah ditetapkan dalam standar nasional perpustakaan walau Batoe Api merupakan taman bacaan masyarakat.

\section{Kontribusi Pada Keilmuan}

Penelitian ini merupakan kajian dalam bidang ilmu perpustakaan yang mengkaji tentang hubungan pemanfaatan koleksi bahan pustaka dengan memenuhi kebutuhan informasi pengguna. Hasil penelitian ini dapat menjadi dasar untuk penelitian selanjutnya atau penelitian bidang sejenis mengenai bagaimana hubungan pemanfaatan koleksi bahan pustaka dengan memenuhi kebutuhan informasi pengguna.

\section{Pernyataan Minat Kajian}

Peneliti bernama Thalia Rizky Augustine memiliki minat kajian dalam bidang pemanfaatan koleksi perpustakaan. Peneliti bernama Prijana memiliki minat kajian dalam bidang metodologi penelitian sosial, statistika sosial, dan kebijakan informasi. Peneliti bernama Saleha Rodiah memiliki minat kajian dalam bidang pemasaran informasi, pemberdayaan masyarakat, dan bibliotherapy.

\section{Kontribusi Peneliti}

Peneliti dengan nama Thalia Rizky Augustine melakukan survei, wawancara, pengumpulan data dengan cara studi pustaka, serta analisis data.

\section{DAFTAR PUSTAKA}

Bungin, H. M. B. (2005). Metode penelitian kuantitatif. Jakarta: Kencana Prenada Media Grup.

Dahlan, A. (2015). Definisi sampling serta jenis metode dan teknik sampling. Eureka Pendidikan. Retrieved from https://www.eurekapendidikan.com/2015/09/definisisampling-dan-teknik-sampling.html

Direktorat Pendidikan Masyarakat. (2003). Pedoman pengelolaan Taman Bacaan Masyarakat (TBM). Jakarta: Direktorat Pendidikan Masyarakat.

Hadid, M. (2017). Pemanfaatan koleksi pustaka tropis Wanadri dalam memenuhi kebutuhan informasi pengguna (Skripsi) [Universitas Padjadjaran, Bandung]. Retrieved from https://repository.unpad.ac.id/frontdoor/index/index/year/2020/docld/31289

Jukardi, A. (2017). Minat baca warga Sumedang masih rendah. Pikiran Rakyat. Retrieved from https://www.pikiran-rakyat.com/jawa-barat/pr-01275072/minat-baca-wargasumedang-masih-rendah-394476

Krisvaresi, J. S. (2013). Pemanfaatan koleksi buku teks dalam memenuhi kebutuhan informasi siswa di SMAN 3 Bekasi (Skripsi) [Universitas Padjadjaran, Bandung]. Retrieved from http:// https://repository.unpad.ac.id/frontdoor/index/index/year/0000/docld/126894 
Prijana, Winoto, Y., \& Yanto, A. (2016). Metode penelitian perpustakaan dan sains informasi. Bandung: Unpad Press.

Prijana, \& Yanto, A. (2020). Metode penelitian perpustakaan dan sains informasi. Bandung: Simbiosa Rekatama Media.

Rakhmat, J. (2012). Metode penelitian komunikasi. Bandung: Remaja Rosdakarya.

Rukmana, E. N., Agustini, N., \& Yusup, P. M. (2015). Kegiatan pelayanan perpustakaan di Perpustakaan Batu Api. Jurnal Kajian Informasi \& Perpustakaan, 3(2), 235-252. https://doi.org/10.24198/jkip.v3i2.10000

Sugiyono. (2009). Metode penelitian bisnis (Pendekatan kualitatif, kualitatif, dan R\&D). Bandung: Alfabeta.

Sugiyono. (2012). Metode penelitian kuantitatif, kualitatif, dan R\&D. Bandung: Alfabeta.

Sutarno. (2008). Membina perpustakaan desa. Jakarta: Sagung Seto.

Wardani, A. I. (2013). Pelaksanaan program Taman Bacaan Masyarakat (TBM) Keliling sebagai upaya peningkatan minat baca masyarakat di Desa Getas Kecamatan Kaloran Kabupaten Temanggung (Skripsi) [Universitas Negeri Yogyakarta, Yogyakarta]. Retrieved farom https://eprints.uny.ac.id/21563/

Yusup, P. M., \& Subekti, P. (2010). Teori dan praktik penelusuran informasi (Information retrieval). Jakarta: Kencana Prenada Media Grup. 